\title{
RELATIONSHIP BETWEEN RECURRENT APHTHOUS STOMATITIS WITH IRON DEFICIENCY ANEMIA
}

\author{
HUBUNGAN ANTARA STOMATITIS AFTOSA REKUREN DENGAN \\ ANEMIA DEFISIENSI BESI
}

\author{
Nurdiana, Pocut Astari \\ Department of Oral Medicine, Faculty of Dentistry, Universitas Sumatera Utara \\ Jalan Alumni No. 2, Kampus USU, Medan 20155 \\ E-mail: nurdiana@usu.ac.id
}

\begin{abstract}
Recurrent aphtous stomatitisis a recurrent oral ulcer. Clinically recurrent aphtous stomatitis is easy to diagnose, but its etiology and pathogenesis remain unclear because it has no single or specific cause. The main predisposing factors associated with recurrent aphtous stomatitis are genetic factors, hematological and immunologic abnormalities, local factors such as trauma, and smoking cessation. Several studies have shown that hematological abnormalities can affect the oral mucosa and cause recurrent aphtous stomatitis. The purpose of this study was to examine the relationship between recurrent aphthous stomatitis and iron deficiency anemia, as well as the relationship between recurrent aphthous stomatitis and hematological status. The subjects consist of 59 recurrent aphtous stomatitis patients and 60 control patients. A full blood examination was carried out for all subjects. Hemoglobin level, mean corpuscular volume, mean corpuscular hemoglobin, mean corpuscular hemoglobin concentration, and serum iron level are determined for each subject.The result of this study showed that there is no significant difference in hemoglobin level, mean corpuscular volume, mean corpuscular hemoglobin, mean corpuscular hemoglobin concentration, and serum iron level with $p$-value of $0.714,0.395$, $0.809,0.497$, and 0.368 , respectively. The result also showed that there is no significant difference in iron deficiency anemia status between the recurrent aphtous stomatitis and control group $(p=0,7)$. Therefore, it can be concluded that there is no relationship between iron deficiency anemia and recurrent aphtous stomatitis incidence.
\end{abstract}

Keywords: recurrent aphtous stomatitis, iron deficiency anemia, ulcer

\begin{abstract}
Abstrak
Stomatitis aftosa rekuren adalah ulser berulang di rongga mulut. Stomatitis aftosa rekuren secara klinis mudah didiagnosis, tetapi etiologi dan patogenesisnya masih belum jelas karena tidak memiliki penyebab tunggal atau spesifik. Faktor predisposisi utama yang terkait dengan stomatitis aftosarekuran adalah faktor genetik, kelainan hematologis dan imunologis, faktor lokal seperti trauma, dan berhenti merokok. Beberapa penelitian menunjukkan bahwa kelainan hematologis dapat mempengaruhi mukosa mulut dan menyebabkan stomatitis aftosarekuren. Tujuan dari penelitian ini adalah untuk menguji hubungan antara stomatitis aftosarekurendan anemia defisiensi besi, serta hubungan antara stomatitis aftosarekurendan status hematologi. Subjek terdiri dari 59 pasien stomatitis aftosarekurendan 60 pasien kontrol. Pemeriksaan darah lengkap dilakukan untuk semua subjek. Tingkat hemoglobin, rata-rata volume sel darah (mean corpuscular volume), rata-rata hemoglobin (mean corpuscular hemoglobin), rata-rata konsentrasi hemoglobin (mean corpuscular hemoglobin concentration), dan kadar besi serum ditentukan untuk setiap subjek. Hasil penelitian ini menunjukkan bahwa tidak ada perbedaan yang signifikan dalam kadar hemoglobin, rata-rata volume sel darah, rata-rata hemoglobin, rata-rata konsentrasi hemoglobin, dan kadar besi serum dengan nilai p-value masing-masing sebesar 0,714, $0,395,0,809,0,497$, dan 0,368. Hasil penelitian juga menunjukkan bahwa tidak ada perbedaan yang signifikan dalam status anemia defisiensi besi antara stomatitis aftosa rekuren dan kelompok kontrol $(p=0,7)$. Oleh karena itu, dapat disimpulkan bahwa tidak ada hubungan antara anemia defisiensi besi dan stomatitis aftosa rekuren.
\end{abstract}

Kata kunci: Stomatitis aftosa rekuren, anemia defisiensi besi, ulser 


\section{INTRODUCTION}

Recurrent aphtous stomatitis is a common disease characterized by development of painful recurrent, solitary or multiple ulcerations of the oral mucosa where the ulcers heal spontaneously and there are no other signs of any other disease. ${ }^{1}$ Clinically, recurrent aphthous stomatitis occur in three different clinical morphological variants with number and size of the ulcers are the two main criteria used to divide ulcers into three forms which is minor, major, and herpetiform. ${ }^{2,3}$ Recurrent aphthous stomatitis is one of the most common oral mucosal lesions that physicians and dentists encounter and affect 2-66\% of the international population. Minor type is the most common form of childhood recurrent aphthous stomatitis, major type has a typical onset after puberty and can persist for the remainder of an individual's life, and herpetiform type first occurs in the second decade of life. ${ }^{2}$

Recurrent aphthous stomatitis is a disorder of unknown etiology that may cause significant morbidity. ${ }^{2}$ Despite their distinct characteristics, all forms of recurrent aphthous stomatitis have a significant impact on quality of life and interfere with activities of daily living. The ulcer is typically very painful so, it commonly interferes with eating for several days. ${ }^{1}$ The major factors presently linked to recurrent aphthous stomatitis include genetic factors, haematologicalor immunologic abnormalities, and local factors such as trauma, and smoking. ${ }^{5}$

Hematologic deficiency, particularly of serum iron, folate or vitamin B12, appears to be an etiologic factor in 5\%-10\% patients with aphthous-like ulcers although these sometimes occur on keratinized mu$\operatorname{cosa}^{5}$ Another literature stated that up to $20 \%$ of patients are deficient of iron, folic acid (folate), or vitamin B. ${ }^{2}$

Hence the aim of the study was to examine the relationship between recurrent aphthous stomatitis and iron deficiency anemia. Furthermore, the relationship between recurrent aphthous stomatitis and hematological status was also examined.

\section{MATERIALS AND METHODS}

The study was conducted at Universitas Sumatera Utara Dental Hospital, Medan. This hospital was chosen because it is one of the dental hospitals in Medan City which has special installation for Oral Medicine. Hemoglobin level, mean corpuscular volume, mean corpuscular hemoglobin, mean corpuscular hemoglobin concentration, and serum iron levels examination was performed at Pramita Clinical Laboratory.
The recurrent aphthous stomatitis group consisted of 59 patients. The patients included in this group are patients who have only minor recurrent aphthous stomatitis with no other oral mucosal diseases. Patients also have noknown systemic disease or any drug history, not using orthodontic appliance and gave their consent. The control groups are consisted of 60 patients with normal oral conditions and no history of recurrent aphthous stomatitis.

A full blood examination was carried out for all subjects (recurrent aphthous stomatitis and control groups). Hemoglobin level, mean corpuscular volume, mean cell hemoglobin, mean corpuscular hemoglobin, mean corpuscular hemoglobin concentration, and serum iron level are determined for each subject. The laboratory normal values for hemoglobin level were 3.2-17.3 gr/dL (male) and 11.7$15.5 \mathrm{gr} / \mathrm{dL}$ (female). The laboratory normal value for mean corpuscular volume was 80-100 fL, mean corpuscular hemoglobin was $26-34 \mathrm{pg}$, and for mean corpuscular hemoglobin concentration was 32-36 $\mathrm{gr} / \mathrm{dL}$ for both male and female. Meanwhile, the laboratory normal value for serum iron level was 65$175 \mu \mathrm{g} / \mathrm{dL}$ (male) and 50-170 $\mu \mathrm{g} / \mathrm{dL}$ (female). Iron deficiency anemia was determined if hemoglobin level, red blood cells morphology (mean corpuscular volume, mean corpuscular hemoglobin, and mean corpuscular hemoglobin concentration), and serum iron level are less than normal.

The hemoglobin levels, mean corpuscular volume, mean corpuscular hemoglobin, mean corpuscular hemoglobin concentration, and serum iron level were coded as normal and reduced and analyzed using a Statistical Package for Social Science computer program. Statistical analysis to compare patients with recurrent aphthous stomatitis and control group was performed with Chi-square test. A $p$ value of $\leq 0.05$ was considered significant.

\section{RESULTS}

Characteristics of recurrent aphthous stomatitis and control group in 119 patients based on age and sex are shown in table 1. It was shown that the mean age for recurrent aphthous stomatitis group was $21.44 \pm$ 2.82 and the mean age group for control group was $22.40 \pm 1.90$. It was also shown more female subjects than male in both groups. 
Table 1. Study participant's characteristics of recurrent aphthous stomatitis and control group

\begin{tabular}{lcc}
\hline \multicolumn{1}{c}{ Parameters } & $\begin{array}{l}\text { Recurrent } \\
\text { Aphthous } \\
\text { Stomatitis }\end{array}$ & Control \\
& 59 & 60 \\
No. of participants & $21.44 \pm 2.82$ & $22.40 \pm 1.90$ \\
Age (Mean \pm SD) & $12 / 47$ & $12 / 48$ \\
Gender (Male/ & & \\
Female) & & \\
\hline
\end{tabular}

The relationship of hemoglobin level, mean corpuscular volume, mean corpuscular hemoglobin, mean corpuscular hemoglobin concentration, and serum iron level in recurrent aphthous stomatitisgroup and control group are shown in table 2 . No statistically differences between recurrent aphthous stomatitis group and control group in terms of hemoglobin level, mean corpuscular volume, mean corpuscular hemoglobin, mean corpuscular hemoglobin concentration, and serum iron level with $p$-value of $0.714,0.395,0.809,0.497$, and 0.368 , respectively.

Table 2. The relationship of hemoglobin level $(\mathrm{Hb})$, mean corpuscular volume (MCV), mean corpuscular hemoglobin (MCH), mean corpuscular hemoglobin concentration (MCHC), and serum iron level in recurrent aphthous stomatitis (RAS) group and control group

\begin{tabular}{cccccc}
\hline \multirow{2}{*}{ Test } & Group & Total & Normal & Low & N-value \\
& & $\mathrm{N}$ & $\mathrm{N}(\%)$ & $3(2.52)$ & 0.714 \\
$\mathrm{Hb}$ & RAS & 59 & $56(47.06)$ & $4(3.36)$ & \\
& Control & 60 & $56(47.06)$ & $5(4.20)$ & 0.395 \\
$\mathrm{MCV}$ & RAS & 59 & $54(45.38)$ & $8(6.72)$ & \\
& Control & 60 & $52(43.70)$ & $7(5.88)$ & 0.809 \\
$\mathrm{MCH}$ & RAS & 59 & $52(43.70)$ & $8(6.72)$ & \\
& Control & 60 & $52(43.70)$ & $9(7.56)$ & 0.497 \\
$\mathrm{MCHC}$ & RAS & 59 & $50(42.02)$ & $12(10.08)$ & \\
& Control & 60 & $48(40.34)$ & $9(7.56)$ & 0.368 \\
Serum & RAS & 59 & $50(42.02)$ & $13(10.92)$ & \\
Iron & Control & 60 & $47(39.50)$ & & \\
\hline
\end{tabular}

$p$-value of Chi-square test

The relationship between iron deficiency anemia group and recurrent aphthous stomatitis are shown in table 3. No statistically differences between recurrent aphthous stomatitis and iron deficiency anemia with $p$-value of 0.717 .

Table 3. The relationship between iron deficiency anemia group and recurrent aphthous stomatitis

\begin{tabular}{lccc}
\hline \multicolumn{1}{c}{ Group } & $\begin{array}{c}\text { Iron Deficiency } \\
\text { Anemia } \\
\mathrm{N}(\%)\end{array}$ & $\begin{array}{c}\text { Normal } \\
\mathrm{N}(\%)\end{array}$ & $p$-value \\
\hline $\begin{array}{l}\text { Recurrent } \\
\text { aphthous }\end{array}$ & $4(3.36 \%)$ & $55(46.22 \%)$ & 0.717 \\
$\begin{array}{l}\text { Stomatitis } \\
\text { Control }\end{array}$ & $3(2.52 \%)$ & $57(47.9 \%)$ & \\
\cline { 1 - 2 } Total & $7(5.88 \%)$ & $112(94.12 \%)$ & \\
\hline$p$-value of Chi-square test & &
\end{tabular}

\section{DISCUSSION}

Recurrent aphtous stomatitis usually occurs between second and third decade of life which normally first arises in childhood or adolescence, predominantly between the ages of 10 and 19 years, with the frequency decreasing in subsequent years.It is in accordance with the result of this study that showed the mean age for recurrent aphthous stomatitis group was $21.44 \pm 2.82$. In children and in some adult communities who are affected, the incidence of recurrent aphthous stomatitis is higher in women and girls than in men or boys. ${ }^{1,6}$ This study also showed more female subjects in recurrent aphthous stomatitis groups. This high prevalence in women can be explained by thefact that women seek more medical attention. ${ }^{7}$

Although several etiologic factors have been proposed, the exact causes of recurrent aphthous stomatitis are still not very clear. Previous studies of tissue infiltrated mononuclear cells in recurrent aphthous stomatitis specimens favor the role of cellmediated cytotoxicity in its immunopathogenesis. ${ }^{8}$

A variety of underlying disorders maypredispose patients to develop recurrent aphthous stomatitis, including iron deficiency anemia, neutropenia, andfolic acid or vitamin B12 deficiency, as well as a selectivevitamin B12 resorption defect. ${ }^{3}$ Multiple nutritional deficiencies including deficiencies of vitamins $\mathrm{B} 1, \mathrm{~B} 2, \mathrm{~B} 6$, and $\mathrm{B} 12$, folate, iron, and ferritin are reported to be the possible etiologies of recurrent aphthous stomatitis. ${ }^{8}$ Hematinic deficiencies are found in $20 \%$ of patients with recurrent 
aphthous stomatitis. It was also been reported that hematinic deficiency twice common in recurrent aphthous stomatitis patients as compared to controls. ${ }^{9}$

Iron deficiency anemia is defined as a reduction in total body iron to an extent that iron stores are fully exhausted, and some more degree of tissue iron deficiency is present. ${ }^{5}$ Iron deficiency anemia occurs when iron deficiency is severe enough to diminish erythropoiesis and cause the develop- ment of anemia. ${ }^{10}$ Various metabolic processes require iron to function, including oxygen transport, deoxyribonucleic acid synthesis, and electron transport. Therefore, iron is very important for living organisms. ${ }^{11}$ Iron deficiency causes microcytic anemia. It is also believed that RAS patients with anemia and lower hemoglobin levels have reduced capacity of the blood to carry oxygen to oral mucosa, finally resulting in atrophy of oral mucosa. In addition, iron is essential to the normal functioning of oral epithelial cells. ${ }^{8}$ In practice, anemia is usually discovered and quantified by measurement of the red blood cells count, hemoglobin concentration, and hematocrit. $^{10}$

Globally, iron deficiency anemia is a serious health threat resulting in an estimated 841,000 deaths. ${ }^{5}$ Higher rates were also found in pregnant women and users of aspirin and/or antacids. ${ }^{11}$ The most common cause of iron deficiency anemia in adult males and post-menopausal women is bleeding, meanwhile in women of childbearing age was lactation or menstruation. ${ }^{5}$ Other causes of iron deficiency anemia include inadequate intake of iron in the dietary and malabsorption of iron due to hypochlorhydria and diarrhea. ${ }^{1}$

Diagnosis of iron deficiency anemia can be based on clinical diagnosis such as koilonychia, neuropathy, angular cheilitis, and depapillation of tongue. Meanwhile, laboratory diagnosis may yield microcytic and hypochromic and peripheral smear show abnormal forms of red blood cells. There is a reduced hemoglobin level, as low as $4 \mathrm{~g} / 100$ milliliter. There is normal or slightly reduced red blood cells count. Mean corpuscular volume, mean corpuscular hemoglobin and mean corpuscular hemoglobin concentration are all reduced. ${ }^{1}$ A definitive diagnosis of iron deficiency anemia requires evidence that iron stores are full depleted and is usually based on the finding of low serum iron, low transferrin saturation, and low ferritin. The most accurate initial diagnostic test for iron deficiency anemia is the serum ferritin level. ${ }^{5}$ In this study the diagnosis of iron deficiency anemia based on hemoglobin, mean corpuscular volume, mean corpuscular hemoglobin, mean corpuscular hemoglobin concentration, and serum iron.

Anemia and hematologic deficiencies may be etiologicfactors for recurrent aphthous stomatitis. ${ }^{8}$ Several hematologic deficiencies have been found to be more common in patients with recurrent aphthous stomatitis than in the general population. Anemia, possibly caused by these deficiencies, was found in $34.4 \%$ of patients with recurrent aphthous stomatitis versus $6.9 \%$ of controls. ${ }^{4}$

Iron deficiency anemia should be suspected in every case of recurrent aphthous stomatitis when no other obvious causes are identified. ${ }^{5} \mathrm{~A}$ recent study found that deficiencies of vitamin B12, folate, and iron, occurring alone or together, have been associated with recurrent aphthous stomatitis in patients of all ages. ${ }^{4}$ Previous studies showed that 57 (20.9\%), 55 (20.1\%), 13 (4.8\%) and 7 (2.6\%) of 273 recurrent aphthous stomatitis patients have deficiencies of hemoglobin, iron, vitamin B12, and folic acid, respectively. Previous recurrent aphthous stomatitis study by Sun et al. described deficiencies of vitamins B1, B2, B6 and B12, folate, iron, ferritin and hemoglobin in a portion of recurrent aphthous stomatitis patients. This study also showed that hemoglobin, serum iron, vitamin B12, and folic acid deficiencies can be detected in 20-43\%, 19 $36 \%, 4-12 \%$, and $2-6 \%$ of recurrent aphthous stomatitis patients, respectively, depending on different subtypes of recurrent aphthous stomatitis patients. ${ }^{12}$ In this study, iron deficiency anemia was determined with hemoglobin level, mean corpuscular volume, mean cell hemoglobin, mean corpuscular hemoglobin, mean corpuscular hemoglobin concentration, and serum iron.

It is believed that recurrent aphthous stomatitis patients with anemia and lower hemoglobin levels have reduced capacity of the blood to carry oxygen to oral mucosa, finally resulting in atrophy of oral mucosa. In addition, iron is essential to the normal functioning of oral epithelial cells. Oral epithelial cells have a high turnover rate. Therefore, deficiencies of iron, vitamin B12, and folic acid may result in oral epithelial atrophy. Atrophic oral epithelium in hematinic-deficient patients may explain why some patients with hematologic deficiencies are prone to have recurrent aphthous stomatitis. Iron deficiency anemia is also believed to be cause by the impaired cellular immunity, deficient bactericidal activity of polymorphonuclear leukocytes, inadequate antibody response, and epithelial abnormalities attributed to iron lack. $^{5}$

The result of this study showed no statistically differences between recurrent aphthous stomatitis group and control group in terms of hemoglobin 
level, mean corpuscular volume, mean corpuscular hemoglobin, mean corpuscular hemoglobin concentration, and serum iron level. Furthermore, there were also no statistically differences between recurrent aphthous stomatitis and iron deficiency anemia. Several studies have suggested the importance of hematological parameters in patients with recurrent aphthous stomatitis, whereas controversies exist. ${ }^{13} \mathrm{~A}$ study reveal that the frequency of hematologic deficiencies was $56.2 \%$ in 32 adult patients with recurrent aphthous stomatitis versus $7 \%$ of controls living in the same geographical area. ${ }^{4}$ Moreover, replacement therapy with hematinic for recurrent aphthous stomatitis patients with deficiencies of corresponding hematinic can result in a significant clinical improvement or at least a reduction in frequency and severity of their oral aphthous ulcers. ${ }^{8}$ Study by Babaee showed that red blood cells and platelets had higher level in case group whereas mean corpuscular volume and mean corpuscular hemoglobin had lower level. Accordanceto hemoglobin there was no significant difference between the case and control group, however in both groups' hemoglobin level was lower than the normal range. Consequently, the evaluation of hematinic parameters in recurrent aphthous stomatitis patients needs to be studied extensively in many aspects and further studies. ${ }^{13}$

Meanwhile, previous study further explains why RAS itself may be an important factor causing anemia and hematinic deficiencies in RAS patients. ${ }^{14}$

\section{REFERENCES}

1. Ghom AG, Ghom (Lodam) SA. eds. Textbook of oral medicine. $3^{\text {rd }}$ ed., New Delhi: Jaypee Brother Medical Publishers (P) Ltd., 2014: 359-63, 858-9.

2. Mirowski GW. Aphthous stomatitis $<$ http://emedicine.medscape.com/article/1075570-overview $>(16$ May2018).

3. Altenburg A, El-Haj N, Micheli C, Puttkammer M, Abdel-NaserMB, ZouboulisCC.The treatment of chronic recurrent oral aphthous ulcers. Dtsch Arztebl 2014; 111: 665-73.

4. Edgar NR, Saleh D, Miller RA.Recurrent aphthous stomatitis: a review.J Clin Aesthet Dermatol 2017; 10(3): 26-36.

5. Glick M. eds. Burket's oral medicine. $12^{\text {th }}$ ed., Connecticut: People's Medical Publishing House, 2015: 73-7, 440-1.

6. Thoppay JR. Aphthous ulcershttp: //emedicine. Medscape.com/article/867080-/overview\#showall (26 April 2018).

7. Queiroz SIML, de Medeiros AMC, de Vasconcelos Gurgel BC, da Silva MVA, de Oliveira PT, da Silveira EJD. Recurrent aphthous ulceration: an epidemiological study of etiological factors, treat-
Study of Lin suggested that even thesmall oral ulcerations may impede the food intake byminortyped recurrent aphthous stomatitis patients. ${ }^{8}$ The majortype recurrent aphthous stomatitis patients often have severer and larger recurrent oral ulce rations than minor type patients. ${ }^{12}$ These severer ulcerative lesions may cause burning sensation and pain oftheoral mucosa when the patients eat salty andspicy food stuffs. The eating difficulty may result inreduced food intake that in turn leads to anemia and hematinicdeficiencies in a certain percentage of recurrent aphthous sto-matitis patients. ${ }^{8}$

In conclusion, this research suggested that there was no relationship between recurrent aphthous stomatitis and iron deficiency anemia. Meanwhile there're also no relationship between recurrent aphthous stomatitis and hematological status i.e. hemoglobin level, mean corpuscular volume, mean corpuscular hemoglobin concentration, and serum iron level.

\section{ACKNOWLEDGEMENT}

The acknowledgments are addressed to The Research Institution (Lembaga Penelitian) of Universitas Sumatera Utara for funding this research by awarding the Talenta Grant 2017. The author would like to offer the outmost gratitude to this institution for fully supporting and funding of this review.

ment and differential diagnosis. An Bras Dermatol 2018;93(3):341-6.

8. Lin HP, Wu YH, Wang YP, Wu YC, Chang JYF, Sun A. Anemia and hematinic deficiencies in antigastric parietal cell antibody-positive or all autoantibodies-negative recurrent aphtous stomatitis patients. Journal of the Formosan Medical Association 2016; 116: 99-106.

9. Khan NF, Saeed M, Khan AA. Correlation between hematological parameters and recurrent aphthous stomatitis. J Pak Dent Assoc 2010; 19(2): 124-8.

10. Maakaron JE. Anemia<http://www.http://emedicine. medscape.com/article/198475-overview> (26 March 2017).

11. Harper JL. Iron deficiency anemia <http:// www. http://emedicine.medscape.com/article/202333-overview\#a1> (26 March 2017).

12. Sun A, Chen HM, Cheng SJ, Wang YP, Chang JYP, Wu YC, et al.Significant association of deficiency of hemoglobin, iron, vitamin B12, and folic acid and high homocysteine level with recurrent aphthous stomatitis. J Oral Pathol Med 2015; 44: 300-5. 
13. Babaee N, Hosseinkazemi H, Pouramir M, Baboli OK, Salehi M, Khadir F, et al. Salivary oxidant/ antioxidant status and hematological parameters in patients with recurrent aphthous stomatitis. Caspian J Intern Med 2016; 7(1):13-8.
14. Kozlak ST, Walsh SJ, Lalla RV. Reduced dietary intake of vitamin B12 and folate in patients with recurrent aphthous stomatitis.JOral Pathol Med 2010; 39: 420-3. 